\title{
Forgotten children: a socio-technical systems analysis of the 2004 and 2015 forced child labour reports from Indian cottonseed farms
}

\author{
Rounaq Nayak $^{1}$ (D) . Louise Manning ${ }^{2}$
}

Accepted: 3 July 2021

(c) The Author(s), under exclusive licence to Springer Science+Business Media, LLC, part of Springer Nature 2021

\begin{abstract}
Using a systems analysis approach, the authors analyse forced child labour incidents in Indian cottonseed farms in the years 2003/04 and 2014/15, and explore the role played by human factors in contributing to the illegal use of child labour in the Indian agri-food sector. National policies on labour welfare and rights are reviewed through the case studies used as a lens to explore wider issues associated with forced child labour in supply chains. The study highlights the evolution of organised crime in India with regards to the reliance on forced child labour, using the four conceptual dimensions of modern slavery established by the UK Home Office in 2017. The study does identify limitations and flaws associated with designing policies based on a "work-as-imagined" philosophy and demonstrates how the use of maturity modelling can explore how exploitation, corruption and organised crime is framed and can become more formalised over time.
\end{abstract}

Keywords Child labour · Organised Crime $\cdot$ Sociotechnical Systems $\cdot$ Policy implications $\cdot$ Asia $\cdot$ India

Rounaq Nayak

RNayak@harper-adams.ac.uk

Louise Manning

Louise.Manning@rau.ac.uk

1 Food, Land and Agribusiness Management Department, Harper Adams University, Newport TF10 8NB, UK

2 School of Agriculture, Food and the Environment, Royal Agricultural University, Cirencester, Gloucestershire GL7 6JS, UK 


\section{Introduction}

Labour standards and welfare of people working in food or textile supply chains is an extrinsic attribute associated with any product. Forced and trafficked child labour has attracted significant global attention (Antonopoulos et al. 2013) due to increasing consumer interest in appropriate norms and verification measures to ensure that the supply chain consistently meets expected standards. One such verification measure that consumers rely on is the United Nations' (UN) 17 Sustainable Development Goals (SDGs) (United Nations General Assembly 2015), of which seven have a direct impact on child labour and welfare standards - (1) no poverty; (2) zero hunger; (3) good health and wellbeing; (4) quality education; (5) decent work and economic growth; (6) peace and justice strong institutions; and (7) responsible consumption and production.

A significant number of children work within food, textile and feed supply chains in developing countries (Rena 2009; Nepal and Nepal 2012; International Programme on the Elimination of Child Labour 2013). Child labour is defined as "work that deprives children (any person under 18) of their childhood, their potential and their dignity, and that is harmful to their physical and/or mental development" (Hilowitz et al. 2004, p. 16). The very existence of child labour not only hinders the individual child's educational achievements, but also the quality of the education system available to children in a particular geography (town/village) (Grimsrud 2003; Nepal and Nepal 2012). Child labour refers to work that: is mentally, physically, socially or morally dangerous and harmful to children; interferes with children's schooling by depriving them of the opportunity to attend school, obliging them to leave school prematurely, or requiring them to attempt to combine school work and excessively long and manual forms of labour (International Labour Organization 1999 n.d.; Hilowitz et al. 2004). Hence, in this definition, it is not the activity [the action], but the effect of the activity on the child [the consequence] that defines child labour, i.e., whether or not the activity impacts the child's health or their access to education (Grimsrud 2003).

Despite public and private policies to the contrary, national and international reports and studies identify a wide range of factors contributing to the occurrence of child labour. Firstly, policies against child trafficking rarely focus on the labour exploitation dimension, i.e., although most countries have a legal framework to prosecute (child) labour traffickers, successfully prosecuting traffickers is quite often difficult to achieve (Smit 2011). The overall aim of this paper is to analyse the child labour incidents in Indian cottonseed farms in the years 2003-04 and 2014-15 and explore the contributing factors to the use of child labour in the Indian agriculture sector and the role of organised crime groups (OCGs) in the illegal use of child labour. To achieve this, the study has two main objectives:

1. To apply a systems approach to the 2004 and 2015 reports on the illegal use of child labour and use the Accimap method of systems analysis to analyse the human and systemic issues involved in the use of child labour. 
2. To reflect on the similarities and differences in terms of human and systemic factors that led up to these incidents and shed further light on flaws in private/public policy adoption in India, the role of OCGs, the appropriate countermeasures to mitigate risk and potential ways forward to improve public and private policy design in the agriculture labour sector.

The paper is structured as follows: Sect. 1 provides an introduction and Sect. 2 details provides context around agricultural labour in India, its history and evolution. Section 3 gives more background on organised crime groups and their engagement with child labour. Section 4 provides geographic context in considering child labour issues in India. Section 5 defines the methodology and Sect. 6 outlines the findings. Section 7 provides the discussion and the paper closes with the conclusion (Sect. 8).

\section{Agricultural labour in India}

Being a less economically developed country (LEDC), foreign trade is the centre of India's growth strategy with a plan for contributing towards 3.5\% of the world's exports (Directorate General of Foreign Trade 2015). Agriculture contributes to approximately $17.5 \%$ of the GDP (Deshpande 2017) and 13.6\% of total exports (Directorate General of Foreign Trade 2015). India's focus on the production of food grains has led to it being a top producer of several crops such as cotton, wheat, sugarcane, rice, and pulses. In 2013 India accounted for $25 \%$ of the total quantity of cotton produced in the world, and as a result, is the second highest exporter of cotton (Deshpande 2017).

The agriculture sector not only provides food and raw materials, but also employs nearly half of the country's workforce (Sharath 2019). In 2009-10, the agriculture sector employed 53\% of India's total workforce (Labour Employment and Manpower Division 2011). From the 2016 Farming Statistics report and the 2011 LEM report, it can be inferred that agricultural labourers are employees who work on other's lands for a portion of the year in return for wages for the works performed. The 1955 report by the Government of India classified agricultural labourers into two categories (applicable to-date): (1) attached labourers - labourers who are either verbally contracted or contracted through writing, to work on other farmer households. These labourers are not allowed to work on other farms and are contracted to work in both, the homes and farms of their employers. Attached labourers are usually paid in kind (e.g., accommodation and food), and there is a higher prevalence of female and child labour under this category than male. The second category is casual labourers - labourers who are free to work on any farm upon receiving payment for their work. Casual labourers may include small farmers owning small land holdings, landless labourers, tenant labourers, and sharecroppers (Government of India 1955), that are looking for additional supplementary work.

The agricultural labour sector in India is largely unorganised and socio-economically exploited. This can be witnessed by the government's response to the labour 
crisis during the first wave of the recent Covid-19 pandemic. Ghosh (2020) states that the most destructive effect of the pandemic is not the result of the disease, but the poverty and hunger it has forced millions of labourers (including agricultural labourers) into as the economy has slowed down across the country.

In recent years, the rural labour market has been undergoing significant changes due to a structural transformation from reliance on traditional sectors (e.g., informal - agriculture) to modern sectors (e.g., formal - industrial) (Chand and Srivastava 2014). Key reasons for agricultural labour to be looking for work outside the agriculture sector is the low wage rate and the lack of support (especially for women) from the government (Chand and Srivastava 2014; Ghosh 2020). Gulati et al. (2013) suggest that schemes such as the Mahatma Gandhi National Rural Employment Guarantee Scheme (MGNREGS) have led to issues such as scarcity and nonavailability of hired labour for agricultural operations in India as the focus of such schemes is to provide employability in formal sectors. Although providing jobs is not necessarily a negative outcome for the nation's economy, there needs to be a revised scheme in place that ensures steady flow of resource (including labour) to the agriculture sector.

While being a nation that relies on agricultural output, policy makers and legislators have seldom included the agriculture sector and its labourers in the design of its policies and laws (Morgan and Olsen 2015). This has led to the steady weakening of the position for small holders and agricultural labourers. Archaic and often confusing laws and national policies (as highlighted in Table 1) and lack of support for women and child labour has led to a lack of transparency and accountability within the agricultural labour market, leading to increased instances of forced labour in the Indian agriculture sector (Morgan and Olsen 2015).

\section{Organised Crime Groups and their engagement with child labour}

An organised criminal group (OCG) is defined by the United Nations Convention against Transnational Organized Crime (Office on Drugs and Crimes 2004, p.5) as being "a structured group of three or more persons, existing for a period of time and acting in concert with the aim of committing one or more serious crimes or offences ... in order to obtain, directly or indirectly, a financial or other material benefit." Le (2012) determines that organized crime models in the literature can be differentiated in terms of those that consider (a) physical structure and mode of operation (b) those models that focus on illicit activities, economics and enterprise and (c) those models that consider the historical, cultural and social framing of organised crime or alternatively a combination of these factors. Some groups operate through historical, cultural, kinship and ethnic connections (Albanese 2011; Ianni 1972; Le 2012); with collective values, language and modes of operation (Le 2012). Delap (2001) highlights that household poverty and income instability are factors that influence societies where child work occurs. Child trafficking in itself is an organised activity with financial payments or foregoing of debts often forming a transaction in return for the child as a unit of labour (Schrage and Ewing 2005). Children who are "trafficked" 
Table 1 Statutes within the Constitution of India that are designed to protect child labour and their welfare

Act

Objective

The Payment of Wages Act, 1936

The Employees State Insurance Act, 1948

The Minimum Wages Act, 1948

Avoid unnecessary delay in payment of wages, and prevent unauthorised deductions from wages (Government of India 1936)

Provide details regarding self-financing social security and health insurance for Indian workers (Employees' State Insurance Corporation 1948)

Indian labour law that sets the minimum living wage for skilled and unskilled labourers (Government of India 1948)

The Contract Labour (Regulation and Abolition) Act, 1970

Prevent exploitation of contract labour and introduce better conditions of work. Contract labour hired through a contractor (middle-man) is considered to be 'indirect employees (Government of India 1970)

The Bonded Labour System (Abolition) Act, 1976

Prohibit the practice of forced labour and human trafficking (Government of India 1976a)

The Equal Remuneration Act, 1976

The Inter-State Migrant Workmen (Regulation of Employment and Conditions of Service) Act, 1979

The Child Labour (Prohibition and Regulation) Act, 1986

Payment of equal rates of remuneration to men and women workers (Government of India 1976b)

Regulate the condition of service of inter-state labourers and protect workers whose services are required outside their native states in India (Government of India 1979)

Detailed regulations and guidance regarding working conditions and requirements (number of hours, health and safety requirements, log books, holiday entitlement) for children under 15 in certain employment fields (Government of India 1986)

The Unorganised Workers Social Security Act, 2008

Provides social security and welfare to workers of the unorganised sectors, i.e., daily-wage workers, self-employed workers or home-based workers) (Ministry of Law and Justice 2008)

Adapted from Department of Agriculture, Cooperation and Farmers Welfare (2020)

for forced labour, via intermediaries and agents often known to their families are "placed" in exploitative situations (Fitzgibbon 2003). The United Nations (UN) sustainable development goal (SDG) No.8 is to provide decent work and economic growth for workers all over the world and SDG No.4 provision of quality education for all children (United Nations General Assembly 2015). Studies link better education systems to lower rates of child labour (Rena 2009; Venkateswarlu 2015), so child labour challenges delivery of both SDGs.

Hazardous labour standards and forced labour received public attention in 2000, when a report on child trafficking was published in the UK (Hütz-Adams 2010). Following public demands for social responsibility, food businesses (such as Nestlé) invested heavily in redesigning company policies and signing the Harkin-Engel 
Protocol in order to prohibit the worst forms of child labour and child trafficking by 2005 (Chocolate Manufacturers Association 2001; Hütz-Adams 2010; Ruehle et al. 2017). Once signed, the agreement deadline was extended to 2008 then to 2010, questioning commitment to the policy. An investigation carried out by Tulane University in 2009 highlighted that less than $5 \%$ of the children working in cocoa farms (supplying to Nestlé) had benefited from the agreement (O'Keefe 2016). Further, a documentary by Mistrati and Romano (2010) titled "The Dark Side of Chocolate" evidenced continuing existence of child trafficking and forced child labour in cocoa farms supplying Nestlé (Hütz-Adams 2010; Mistrati and Romano 2010). This case illustrates the dilemmas involved between policy design and regulation enforcement, market promotion and labour protection, public authority and public opinion and the failings of an inadequately designed policy drafted by the Chocolate Manufacturers Association (CMA). The sequence of events which lead to continued child labour despite organisations agreeing to national policies and implementing their own private policies reveals a contested complex sociotechnical dynamic. This includes factors in the local work environments, local cultures, organisations and governments (Hütz-Adams 2010; Mistrati and Romano 2010; Ruehle et al. 2017).

As well as a lack of vertical interaction (Kirlik 2011), factors such poverty, inadequate audits, poor communication between stakeholders, inadequate constraints, and value chain complexity influences the use of illegal child labour (International Labour Organization n.d.; Gayi and Tsowou 2016; Ruehle et al. 2017; Burea of International Labor Affairs 2018) leading to a negative supply chain culture (Nayak and Waterson 2016a, b; Pennington 2009). In India, 40 million children are suggested to be working in conditions where they cannot refuse their labour and these children are often trafficked or traded (Srivastava 2019). There have been studies on organised crime in India but they do not focus on child labour (Sharma 1999; Charles 2002; Michelutti and Martin 2017). Child labour in India is now considered in more detail.

\section{Child labour in India}

There are ambiguities in India in employment terms of what constitutes a "child" and "adolescence". The Child Labor Act 1986 (Government of India 1986) dictates that children above the age of 14 can work in family businesses, but not in hazardous industries. However, the Plantations Labor Act, 1951 (Government of India 1951) simply defines a child as one younger than 15 years. Adolescence is defined as the age between 15 and 18 in India (Seth 2013), but between 10 and 19 by the World Health Organisation (United Nations General Assembly 1989). This ambiguity creates a policy challenge when comparing national and international standards and considering in terms of being a child in the Indian context.

Child labour influences the local, national and global job market. Non-compliant businesses prefer hiring child labour as: they are paid lesser than adult labourers or are made to work for free; are easier to control and bully; are easier to traffic to work illegally; work longer hours; and are deemed to be protected through the existence of faulty policies (Venkateswarlu 2004a, b 2015) i.e. they are easier to exploit. Indeed, 
poorly designed policies aimed at increasing adult participation in labour markets can generate greater demand for child labour (Dammert et al. 2018). Utilising child labour reduces adult employment opportunities and associated poverty drives children, especially girls, being sent to work instead of attending school. Unsafe working and living conditions for children on farms impedes physical, social and intellectual growth (Bureau of International Labor Affairs 2018; Grimsrud 2003). Further, uneducated children remain trapped in poverty, and this cycle perpetuates with their children as well (Ruehle et al. 2017), becoming a vicious cycle.

\section{Regulatory approaches to child labour}

The Government of India (GoI) is divided into 52 ministries/departments, including the Ministry of Agriculture and Farmers' Welfare (GoI 2020) which is sub- divided as: the Department of Agriculture, Cooperation \& Farmers' Welfare (DAC\&FW); Department of Agriculture, Research \& Education (DARE); and Department of Animal Husbandry, Dairying \& Fisheries (DAHD\&F). DAC\&FW deals with the development and implementation of policies related to agriculture and farmers' welfare in India. The administrative head of the department is the Secretary who is supported by multiple advisors. The DAC\&FW has a further 27 divisions of which, the Vigilance Division plays a key role in ensuring compliance with policies and protocols in a wide array of policies within the agriculture sector. The Division is involved in: collecting intelligence about corrupt practices committed or likely to be committed by employees of the department; investigating or initiating an investigation into verifiable allegations; processing investigation reports for further consideration of the concerned disciplinary authority; referring matters to the Commission for advice where necessary; introducing barriers to help prevent improper practices and misconduct; examining audits; and carrying out inspections from a vigilance perspective. The Vigilance Division works in tandem with the Central Vigilance Commission (CVC) and the Central Bureau of Investigation (CBI). (DAC\&FW 2019).

Another key ministry within the GoI responsible for child welfare and rights of child labour is the "Ministry of Labour \& Employment". Its main objective is to protect and safeguard the interests of two types of workers: general labourers; and those who constitute the poor, deprived and disadvantaged sections of society. Another objective is to promote the labour force's welfare and social security in both organised and unorganised sectors, in tandem with the process of labour liberalisation. To achieve these objectives, the department enacts and implements various labour laws that regulate the terms and conditions of service and employment for labourers (GoI 2016).

The Constitution of India clearly states that any form of forced labour is prohibited, and that any contravention of this provision is an offence punishable by law (GoI 2015). There are 44 labour-related statutes enacted by the "Ministry of Labour \& Employment" addressing topics such as: minimum wage; accidental and social security benefits; occupational health and safety; conditions of employment; disciplinary action; formation of trade unions; and industrial relations. 
The work sector in India is divided into two categories: unorganised; and organised. The unorganised work sector comprises of "all unincorporated private enterprises owned by individuals or households engaged in the sale and production of goods and services operated on a proprietary or partnership basis and with less than ten total workers" (Sengupta et al. 2007, p. 2), of which the agriculture sector is a part. Table 1 highlights statutes enacted by the Central GoI that are relevant to child labour welfare and rights in the agriculture sector. A survey carried out by the "National Sample Survey Organization", India in 2017-18 highlighted that the total employment in the unorganised sector amounted to approximately 437 million workers, of which $56.3 \%$ worked as labourers in the agriculture sector (National Statistical Office 2019).

The "Ministry of Labour \& Employment" and the "Vigilance Division" within the DAC\&FW should work in tandem to address labour standards in the agriculture sector, and farmers/contractors comply with various statutes and policies at a meso (business) and micro (individual) level. It is the duty of the vigilance officers and labour inspectors to inspect workplaces relating to conditions of work and protection of workers and provide feedback/advice on how any non-compliance could be avoided in the future. In addition, they also must specify if such advised action is simply good practice or a legal obligation. Inspectors have the authority to inspect records, write informally to correct non-compliance or close a site due to breach of regulations. In serious cases, inspectors can recommend prosecution of concerned violators (International Labour Organization 1947; DAC\&FW 2019).

Indian labour welfare public and private policies have considerable design flaws (Venkateswarlu 2015; Bureau of International Labor Affairs 2018). Changes in Indian agriculture and farming policies have coincided with two major institutional changes: globalisation of the food industry (Nayak and Waterson 2019); and international trade liberalisation. Further, economic volatility (International Programme on the Elimination of Child Labour 2013); strong competition between transnational and national corporations (Venkateswarlu 2004a, b, 2015); a lack of regard for, and non-compliance with, public and private child labour policies, as well as inadequate reporting/systems, frame exploitation of child labour in agri-food value chains.

Additionally, policy makers have an idealistic view of formal tasks leading to a disregard of the need to adjust work to match the constantly evolving conditions of work. This leads to the design of policies based a "work-as-imagined" philosophy - this philosophy describes what should be happening under normal working conditions. This philosophy is based on the success of 'Taylor's Principles' as described in the monograph, Scientific Management Theory (Taylor 1911) which prescribes to a detailed breakdown of tasks and activities to improve work efficiency. Safety and welfare were not considered as issues in the monograph. However, it is important for policy makers to design policies based on how work unfolds over time under the pressures of the environment, i.e., a "work-as-done" philosophy (Hollnagel et al. 2013). Intractable work environments and pressures of globalisation (Aas 2007; Nayak and Waterson 2019) have made it difficult for there to be alignment between "work-as-done" and "work-as-imagined". Policies (including labour policies) which are designed a "work-as-done" philosophy are of reflective flexible and adaptive 
systems (Eurocontrol 2013). Such systems allow stakeholders to work around the everyday challenges that they face, while ensuring their welfare and safety.

\section{Summary}

The global consumer base that the Indian agriculture sector supplies are sensitive to issues such as modern-day slavery and the employment of child labour on farms. However, multi-level regulations, core disputes about public agricultural and labour policies, and the shifting balance between various public and private policies are multiple issues where flaws in Indian food and agricultural policies seem evident. Although labour welfare and rights is an important and a highly salient policy arena, it has been brought into sharp relief in modern-day India (Hilowitz et al. 2004; League of Arab States et al. 2019; Seth 2013; Srivastava 2019; Venkateswarlu 2015). Despite the design of policies that prescribe to an ethical approach of "workas-imagined" by stakeholders (government, business, non-governmental organisations (NGOs) etc.) who are not involved in the day-to-day functioning of the Indian agriculture sector, there is an ethical and operational conflict as these stakeholders may not understand or observe the reality of "work-as-done". Reports on the 2003-04 and 2014-15 child labour occurrences in Indian cottonseed farms show weak regard not only for the International Labour Organisation's (ILO) policy on child labour; but also the Indian regulation and policy on employing child labour (Child and Adolescent Labour (Prohibition and Regulation) Act, 1986 ${ }^{1}$ ) and owning large pieces of land (Urban Land (Ceiling and Regulation) Act, 1976 ${ }^{2}$ ) (Venkateswarlu 2004a, b, 2015). The 2004 study reported that $67.2 \%$ of the labourers on cottonseed farms in Gujarat $(\mathrm{GJ})^{3}$ were aged between 8 and 18. In comparison, the 2015 study reported $52.7 \%$ of labourers on cottonseed farms in GJ were between the ages of 8 and 18 (Venkateswarlu 2015). The use of child labour in this context presents an opportunity for labour exploitation and supply chain corruption worthy of further investigation.

\section{Methodology}

\section{The Accimap approach}

The Accimap approach (Rasmussen 1997) is used in this study to analyse reported incidents of child labour. This approach involves the construction of a multi-layered graphical representation in which the causes of the incidents are arranged according to their causal remoteness from the outcome (Branford et al. 2009). Accimaps adopt a control-theory based approach to incident analysis within the context of a sociotechnical system (Rasmussen 1997; Svedung and Rasmussen 2002). According to

\footnotetext{
1 Amended as the CLPR Act, 2016.

2 Repealed in various states in India.

${ }^{3}$ Gujarat is a state on the western coast of India.
} 
this theory, accidents are a result of unexpected, uncontrolled relationships between a system's constituent parts where systems are analysed as whole entities instead of considering them as various parts in isolation (Underwood and Waterson 2014; Nayak and Waterson 2016b). Stakeholders of a complex system interact with a range of factors in their environment, which eventually influences the way they behave. The Accimap method has been used previously to analyse individual accidents such as the Überlingen mid-air collision (Branford 2011) and the 1996 and 2005 E.coli outbreaks in the UK (Nayak and Waterson 2016b). All work situations leave varying degrees of freedom to the actors so they have the ability to choose the means and times of action even when there is a set of instructions or policies in place to follow (Rasmussen 1997).

The agriculture sector consists of transnational as well as local businesses, and farms - both of which are required to have private policies and standard operating procedures in place for every task - this helps achieve maximum efficiency and makes stakeholders responsible for their actions. However, failure to follow regulations and policies to the letter leads to the occurrence of negative events (Hollnagel 2014). The Accimap model for food systems highlighted in Fig. 1 depicts the control of sociotechnical systems over six basic systemic levels:

- Level 1-Government level: Laws and public policies are developed to control the practice of illegal labour practices.

- Level 2-Regulatory bodies and associations: Legislation and public policies are adapted at the local ministerial and non-ministerial enforcement body level into industry rules and guidelines.

- Level 3-Organisational level: Regulatory body rules and public policies are translated into private policies. Organisational protocols and governance structures are organised according to these policies.

- Level 4-Management level: Management ensures that the organisation's policy is implemented, and that there is a high level of compliance with the policies and protocols. In this study management includes large farm owners and middle-men who supply labour and contracts to farmers.

- Level 5-Labour level: The labour in the case of this study are tribal and migrant labourers who are brought to work seasonally on cotton farms, or are made to work on their own loaned-farms as subsistence farmers.

- Level 6-Work, equipment and the environment: The organisation and farm's protocols are performed in these environments by labourers. Policies and regulations are applicable at every element within this level.

There are several advantages of adopting the Accimap approach. By making use of graphical representation, the Accimap approach provides the context for gaining a comprehensive understanding of how and why an incident occurred (Branford et al. 2009). The graphical representation helps analysts compile large amounts of information into one comprehensive diagram by highlighting the multiple causal factors leading to negative events (Jenkins et al. 2010; Nayak and Waterson 2016a). The 
Adapted from Rasmussen (1997)

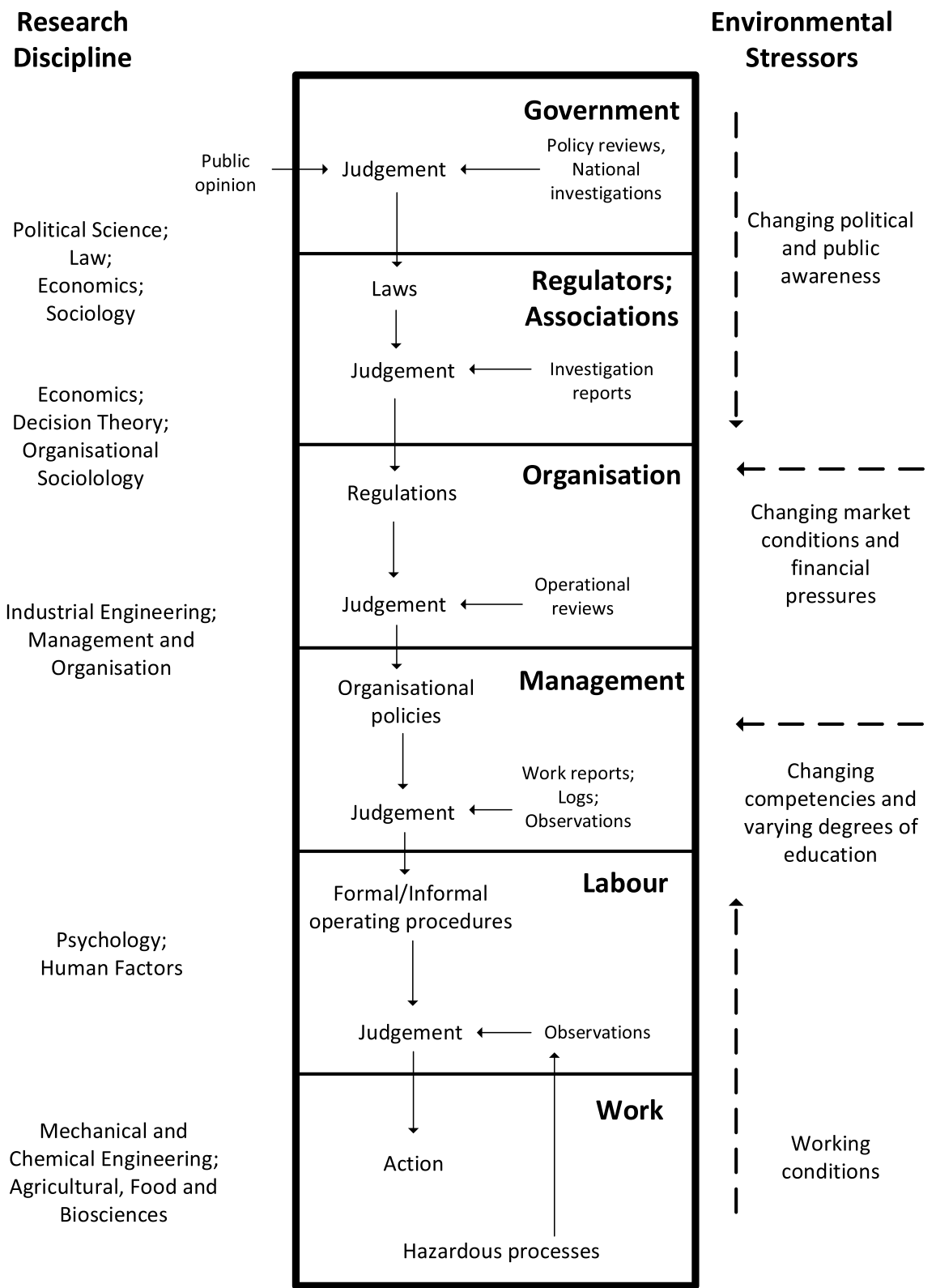

Fig. 1 The structure of a sociotechnical food/feed system. Adapted from Rasmussen (1997) 
Accimap approach aids analysts and incident investigators uncover a diverse set of 'negative incident enabling' factors across the system. This approach highlights that immediate causes of events (e.g., human errors) are the result of higher level factors, thereby, promoting Reason's (2000) systems approach. This approach not only identifies the root cause that led to the incident, but also progressively identifies the causes of each of the factors. By doing so, the Accimap approach helps to identify the decisions, events and conditions that created the environment in which the incident occurred (Branford 2011). Links between causal factors also helps analysts and investigators evaluate complex interactions between various factors, and design holistic interventions with the potential to have an impact across the entire system under investigation. The term causal factors is used by Branford and so for accuracy has been used in this paper. The term causal is used in the context of being a necessary or contributory factor of influence in a given accident or incident but not to imply causality (Branford et al. 2009).

\section{Construction of Accimaps}

The steps for Accimap analyses in this study were adapted from the Branford et al. (2009, pp.205-212). The Accimap analyses of the incidents were performed by the first author. The analyses and their interpretive findings were then reviewed by the second author. While both individuals are food policy researchers, the first researcher has experience in applying human factors methods to complex sociotechnical systems, and the second researcher has experience of applying socio-economic and cultural theory in agri-food supply chains. Upon completion of the analyses, the researchers exchanged and reviewed outputs, and any anomalies were resolved through discussion until a consensus was reached in a similar to the approach described in Underwood and Waterson (2014). In addition to the standardised approach prescribed by Branford et al. (2009), the modified classification of causal factors recommended by Nayak and Waterson (2016a, b) was used i.e., causal factors were classified as "pre-conditions", "direct causes", "indirect causes", "complex causes", and "outcomes." Preconditions are events which either lead to a direct or an indirect cause, but are not causes themselves; direct causes are serious events, which if avoided, would have completely prevented an outcome; indirect causes do not have a straightforward role to play in the consequent outcome, i.e., other causes also contribute to the same outcome; and finally, a complex cause indicates that a cause can be classified as direct as well as indirect as it has had multiple roles to play in the occurrence of a given negative incident e.g. use of illegal child labour.

An in-depth review of The India Committee of the Netherlands reports from 2004 and 2015 was carried out independently by both authors utilising the following approach: construction of a timeline of the events involved in the child labour incidents; identifying causal factors that led to the incidents; identification of the human factors of influence; and considering the systemic levels at which the human factors have influence (see Fig. 1). Table 2 highlights the coding used to construct the Accimap and the resulting Accimaps are presented in Figs. 2 and 3. 
Table 2 Steps used to construct the Accimaps

\begin{tabular}{ll}
\hline Step number & Details \\
\hline 1 & $\begin{array}{c}\text { Large sheet of paper divided into multiple sections, with the headings of the various levels } \\
\text { on the left-hand side } \\
\text { Each incident analysed separately and the negative outcomes to be analysed are identified. } \\
\text { Outcomes inserted into 'Labourers' level of the Accimap }\end{array}$ \\
3 & List of causal factors drawn out. Causal factors are those factors, which if prevented, \\
& would have avoided the negative event \\
4 & Appropriate level for each causal factor identified based on guidelines provided by Bran- \\
& ford et al. (2009) \\
& Identified causal factors were written down on a sticky note and placed at the appropriate \\
& Causal links were inserted, linking factors and demonstrating systemic errors \\
7 & Using Microsoft Visio, the factors were rearranged such that causes leading to the same \\
& outcome(s) in the 'Labourers' level were placed close to each other
\end{tabular}

Adapted from Branford et al. (2009)

Implications of the Accimaps developed in this research are presented under subheadings adapted from the conceptual dimensions stated in Cooper et al. (2017): recruitment; profit; organisation; and control. Table 3 provides an overview of the four conceptual dimensions, their sub-factors and the maturity stages of each of the dimensions in the 2003/04 and 2014/15 illegal child labour incidents.

Tables 4 and 5 describe in detail the causal factors identified in Figs. 2 and 3 respectively. A comparison of the similarities and differences between the two incidents is provided in the discussion in this paper along with a detailed analysis of the inadequacies of current and past labour policy design in India to provide recommendations for policy.

\section{Findings}

Results are considered in terms of each report (Venkateswarlu 2004a, b; 2015) and findings are highlighted singularly and then compared in Sect. 6. The maturity of various causal factors for both incidents are highlighted in detail in Table 3.

\section{The 2003/04 Gujarat child labour incidents}

Children were used in highly labour-intensive plantations to carry out cross pollination, vital in cottonseed production, accounting for approximately $90 \%$ of total labour required, and $45 \%$ of cultivation costs (Venkateswarlu 2004a, b). Most farmers relied on hired labour for carrying out daily activities (86.5\%), 82.5\% being migrant labourers belonging to communities from GJ and Rajasthan and family labour less than $10 \%$ of the total. Workers came to find work in GJ due to perennial droughts in Rajasthan. Out of the total hired labour force, two thirds of those 


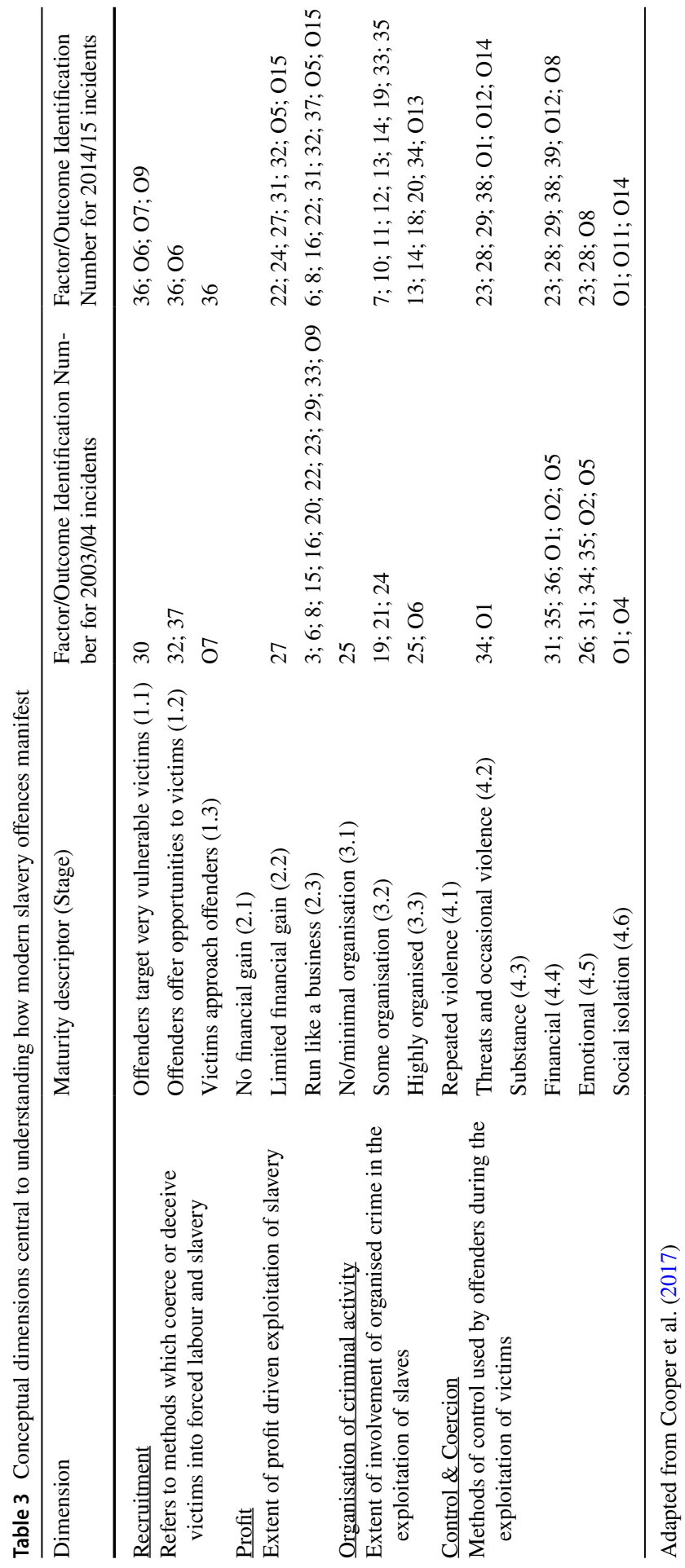


working in cottonseed farms were between the ages of 8 and 18; children below the age of 14 accounting for $34.9 \%$ of the total labour force. The number of girls working was higher than the number of boys $(60.9 \%$ and $39.1 \%$ respectively) as farmers preferred girl children due to their "delicate fingers (nimble fingers)" (Assan and Hill 2011; Singh 2017; Venkateswarlu 2015, p. 9). The rate of pay was between $£ 0.27$ and $£ 0.43$ per day. The rate of pay for child labour being at the lower end of the spectrum and paid directly to their parents. These findings are consistent with a study on Asian children working as hidden labour in lesser developed areas (Webbink et al. 2012).

The Accimap analysis is presented in Fig. 2. Events such as 'families of migrant labourers forcing their children to work' arising from the 'promise of additional wages', acted as reference points to begin analysis at the 'operational management' and 'organisational' levels. The causal factors show gradual deterioration and failure at various points across the value chain. Factors were assimilated in order to analyse individual factors, factors within a system, and the interactions between various factors throughout the whole system (Nayak and Waterson 2016b). Iterative analysis meant that the Rasmussen's 1997 model was further divided into two sub-levels at the 'operational management' level - farmers and middle-men/labour contractors. Sixteen causal factors (one indirect factor-access to limited resources for farmers) were identified across the operational management level, the most for any level in the Accimap.

\section{Recruitment}

The Accimap reveals that illegal use of child labour was not an outcome of individual non-compliances with public and private policies or the inadequacies of public policies alone, but was instead attributable to an accumulation of major factors across multiple systemic levels such as the government's commitment to export, and market demand for illegally produced GM crops. Of all the causal factors identified, $8.7 \%$ were recruitment-related factors. Four causal factors were attributable to the recruitment of forced child labour through coercion and deceit. These factors were

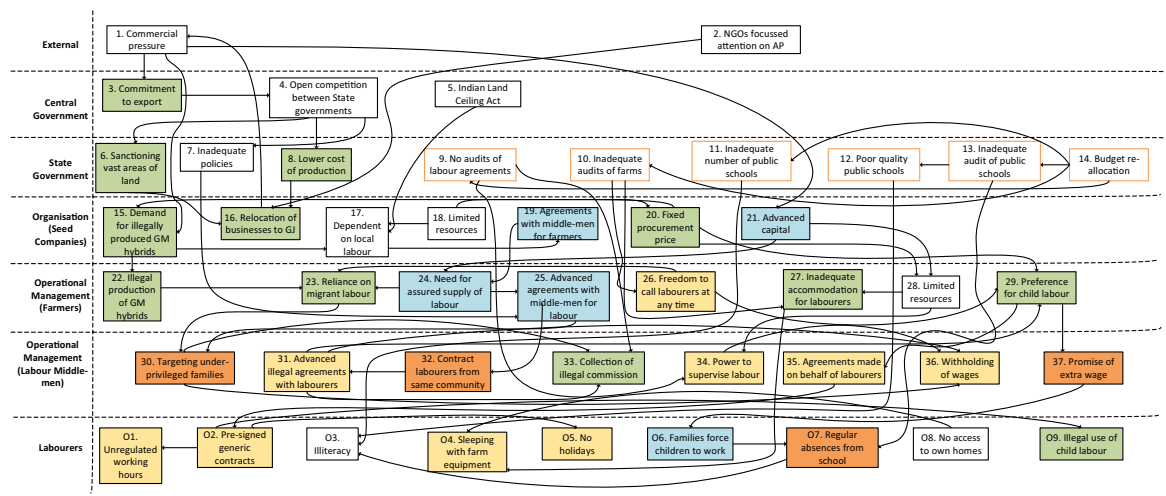

Fig. 2 Accimap diagram of the 2003/04 Gujarat child labour incidents 


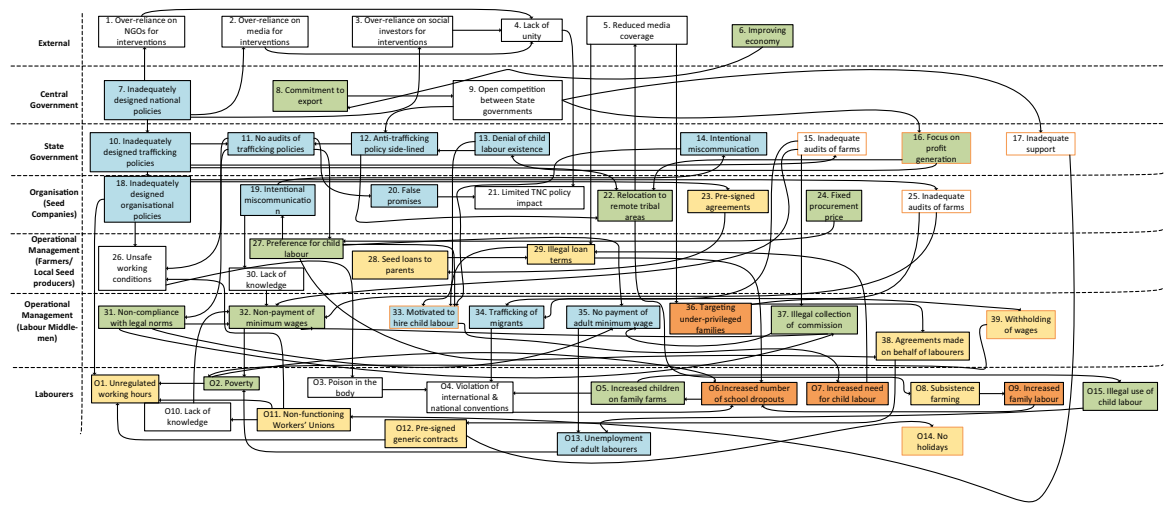

Fig. 3 Accimap diagram of the 2014/15 Gujarat child labour incidents

located primarily within the 'operational management' level; three factors identified at 'middle-men providing labour' level, while only one factor was identified at the 'labourers' level. No other recruitment-related causal factors were identified in the 2003/04 incident.

\section{Profiteering}

Of the causal factors, $26.1 \%$ were profiteering-related. Twelve causal factors located across the sociotechnical system were attributable to stakeholders' need for profit. While only one of these factors was at the 'Central Government' level, two were at the 'State Government' level, and three at the 'organisational' level. Five causal factors were identified across the 'operational management' levels; four at the 'farm' level, and one at the 'middle-men providing labour' level. One factor, which can also be classified as an outcome, was attributable to the 'labourers' level.

At the government levels (Central and State), 25\% of causal factors were linked to the need for the nation to generate profits. Out of a total of 12 factors across the two government levels, only $50 \%$ had been identified in the 2004 report, the remaining 50\% (marked as orange boxes) had to be inferred from other reports (as these were gaps identified through the Accimap analysis), while $75 \%$ of the identified factors were categorised as indirect causal factors. Causal factors, that could not be classified into one of the four conceptual dimensions of forced labour, were identified as indirect causes. The missing causal factors were mostly linked to the quality of inspections by government inspectors (failure to audit labour agreements, farms and public schools; inadequate and poor quality of public schools). Another indirect causal factor linked to profiteering was the reallocation of budgets due to monetary restraints at the 'State government' level. The other indirect causal factors identified at the government levels (open competition between states; the Indian Ceiling Act; and inadequate policies) were mentioned in the 2004 report as distant causes that could have played a minor contextual role.

At the 'organisational' level $43 \%$ of factors such as demand for illegally produced GM hybrids and relocation of business to GJ were attributable to the drive 
Table 4 Explanation of the numbered factors in Fig. 2

Factor Interpretation

identification

number

Commercial pressure to produce influenced stakeholders across two levels - organisational and central government. While the central government had made a commitment to improve national economy, seed companies had been awarded contracts by national and central governments to deliver output. There is also the added risk of the contract being rescinded and being awarded to a rival business

Global news on the extensive use of child labour in Andhra Pradesh led to local NGOs focussing their attention solely on one state

In an attempt to improve the national economy, the central government had made a commitment to export

The central government let local governments compete with each other to get transnational and national seed companies to establish in their states

The Indian Ceiling Act prohibits companies and individuals from owning large pieces of land

In order to tempt seed businesses to establish themselves in GJ (and to outcompete other states), large pieces of land were sanctioned for seed production

Inadequate policies regarding farm operational procedures and sales of public seeds

Cheaper labour, energy and higher subsidies were offered to tempt businesses to establish themselves in GJ

Inspectors from the state government failed to carry out audits of labour agreements signed by labourers and middle-men

conditions
conspectors

11,12 and 13 The government did not ensure that there were an adequate number of high-quality schools providing education to children

Budget was re-allocated to other departments which were deemed to be more important

Illegally produced GM crops generated higher income due to cheaper resourced that went in growing them

Seed businesses relocated to GJ due to favourable conditions for businesses

Seed businesses contracted their work out to local farmers and local labour, who they were dependent on to successfully compete in the value chain

Seed businesses provided limited economic, raw material and training resources to farmers

Seed businesses made agreements with middle-men to hire farmers who would grow cotton seeds and supply seeds back to the businesses

Seed businesses did not want to negotiate the price they would pay for seeds (which they would purchase from the farmers), or the price of raw materials provided to farmers (to grow seeds)

Seed businesses provided and advance to middle-men to be able to hire farmers who could in-turn hire labourers

The demand for illegally produced GM crops from seed companies meant that farmers felt the need to grow such crops

The seasonality of the work meant that farmers needed access to assured continued supply of labour to meet the high demand

Farmers made agreements with 'labour middle-men' to provide cheap labour that would help produce cottonseeds 
Table 4 (continued)

Factor Interpretation

identification

number

26

27

28

29

30

31

32

33

34

35

36

37

According to the contract signed by the labourers, farmers had the right to call labourers to work at any point during the season

Farmers were meant to provide adequate housing for labourers who lived on their farms. However, they did not do so

Farmers had access to limited resources (financial and raw materials)

Farmers preferred child labour as easy to control (make them carry out multiple tasks with minimal resistance), and their smaller and gentler hands

Middle-men targeted under-privileged families as it was easier to make them sign unfavourable contracts

Through pre-signed agreements, middle-men made agreements in advance with labourers about pay, and obtain illegal commission from labourers' pay

Middle-men hired labourers from the same village that they were from

Based on earlier illegal agreements, middle-men collected a commission from the labourers' pay

Middle-men were given the authority to supervise labour on farms (although they had no training to do so)

As most labourers were illiterate, agreements were signed by middle-men

Middle-men withheld labourers' wages if they did not do as they were told (i.e., work over time/send their children to work)

Families were promised extra wages for making their children go to work as labourers

for profits, $28.5 \%$ associated with OCGs connected to child labour, while a further $28.5 \%$ such as dependency on local labour; were classified as indirect causes. $31 \%$ of the factors e.g. illegal production of GM hybrids and reliance on migrant labour identified at the 'operational management' level were linked to profiteering, with a majority $(80 \%)$ at the 'farming operational management' level.

\section{Organisation of criminal activity}

Of the causal factors identified, $10.9 \%$ were organised criminality-related. Four causal factors were attributable to the involvement of OCGs in child labour exploitation focussed across the 'organisational' and 'operational management' (at the farm) levels. Casual factors at the organisational level such as agreements with middlemen for hiring farmers were attributable to exploitation while only $12.5 \%$ of the factors (need for assured supply of labour; and advanced agreements with labour contractors) were at the 'operational management' farmer level.

\section{Control and coercion}

Around one fifth $(19.6 \%)$ of causal factors were control-related. Nine causal factors were attributable to stakeholders' need to control and labour exploitation. Five 
Table 5 Explanation of the numbered causal factors in Fig. 3

\section{Factor identification number Interpretation}

1,2 and 3

4

7, 10, 11, 12 and 18

9

13,14 and 19

15 and 25

20 and 21

$23,28,29$ and 38

26

27
The system and its stakeholders over-relied on NGOs, the media and social investors to identify and eliminate occurrences of child labour. This lead to a culture of complacency and denial by various stakeholders when external stakeholders did not highlight occurrences of child labour

Lack of unity towards what should have been a common goal of abolishing child labour. Most stakeholders shared common goal of generating profits (for a multitude of reasons) generating profit the expense of labour and child welfare was deemed the preferred route

Over-reliance on media by the entire country (India) as a means of helping identify occurrences of illegal child labour meant that various media outlets were unable to focus on a couple of cases in detail

Governments as well as the private sector had a common goal of generating profits this was the leading and sole driver behind their operations

Public policies at the government levels and private policies at the organisational level all mentioned statement and principles of actions to mitigate the use of child labour on farms and within supply chains. However, these policies were designed based on 'work-as-imagined' instead of considering what actually happens within supply chains

Central government let local governments compete with each other to get transnational and national seed companies to establish in their states

Existence of illegal child labour was largely denied at the government level. A reason given when proof of child labour was provided was that children often worked around school hours or during holidays to help out their parents. However, this would still be a violation of international and national conventions as this action would hinder the child's ability to develop social skills and meet their educational needs

Inspectors from the state government and private auditors failed to carry out audits of farms and working conditions

State Government failed to provide adequate support to labourers and seed producers due to inadequate resources and denial of the existence of child labour

Large transnational and national seed companies promised to not use child labour within their supply chains. However, by loaning farms to poverty-stricken labourers, and by making them sign contracts they indirectly forced them to use their own children as a source of labour. They also designed policies that were ambiguous to help achieve their goals through any means necessary

Transnationals relocated to tribal areas to avoid media pressure and then migrant and tribal labourers signed unscrupulous deals

TNCs and local seed producers worked together to make poverty-stricken, migrant and tribal labourers sign unscrupulous deals whereby they would be bonded to work for these stakeholders for a long time with no option to opt-out, making the most of these labourers being illiterate

In an attempt to generate greater profits, labourers who worked on farmers' farms were forced to work under conditions that would have been illegal under The Contract Labour (Regulation and Abolition) Act, 1970

As in the 2003/04 incidents, farmers preferred employing children as they were: cheaper to hire; easier to control; and had finer, small hands for carrying out the jobs required in cottonseed farms 
Table 5 (continued)

Factor identification number Interpretation

30

Farmers, local seed producers and labourers lacked knowledge about various legal rights, the existence of unions, and conditions that needed to be met to be able to hire workers. The acts carried out at this level were mostly due to what stakeholders higher up the hierarchical chain had advised

31,32 and 35

The sole goal of labour contractors was to earn money through both legal and illegal means. Lack of audits and resources, coupled with labourers' lack of knowledge made it easier for labour contractors to carry out illegal tasks such as not provide adults their minimum wage, leading to employment of child labour

33,37 and 39

Labour contractors were motivated to hire child labour due to the abovementioned incentives, and also because it was easier to withhold their wages and collect illegal commissions from children

34 and 36

Labour contractors trafficked migrants to work on farms (not subsistence farms) and targeted underprivileged families as it was easier to carry out unethical practices such as manipulation into working for pre-signed contracts and withholding of wages

causal factors were located across the 'operational management' levels: (one 'farm' level, and four 'middle-men providing labour' level); and four causal factors were attributable to the 'labourers' level (unregulated working hours; signed generic contracts; sleeping with farm equipment; and no holidays) highlighting failings across the system. The 'labourers' level is similar to the 'outcomes' level in Rasmussen's 1997 model. It has been reworded for the purposes of this research as all the final negative outcomes were present at this level. Out of the nine outcomes identified, $44 \%$ of the outcomes were control-related, one outcome (families force children to work) was OCG related, another (regular absences from school) was recruitment related, and one outcome (illegal use of child labour), profit related. The remaining two outcomes (illiteracy; and no access to own homes) could not be classified into any of the conceptual dimensions of forced labour.

\section{The 2014/15 Gujarat child labour incidents}

The 2015 report on child labour incidents in GJ was an outcome of media as well as multiple international reports on the continual use of child labour in cottonseed farms in India, and the poor work conditions they work in. The report was produced as an outcome of a collaborative project between: an independent NGO, "The Indian Committee of Netherlands"; a coalition, "Stop Child Labour"; and a multi-disciplinary research and consultancy service, "Global Research". The following details about the incident are adapted from Venkateswarlu (2015). The research highlighted that children under the age of 14 accounted for $25 \%$ of the total workforce in cottonseed farms in India in 2014/15. As in 2003/04, GJ was the country's largest 
regional producer of cottonseeds and employed 110,000 children (55\% of India's child labour on cottonseed farms). The number of children (ages 15-18) working on such farms in GJ was 281,200 , which was an increase of nearly a half from the number in 2006/07. The report highlighted that cross-pollinators were paid between $6.6 \%$ and $16.6 \%$ below the national minimum wage in GJ. In addition to working long hours, children working in cottonseed fields were exposed to pesticides which were used in high quantities in cottonseed cultivation. Venkateswarlu (2015) highlights that the governments of GJ (where children were trafficked to) and Rajasthan (where children were trafficked from) were in denial about the existence of, and increase in, labour exploitation (between 55 and $58 \%$ of the total child workforce in GJ were truant from school). Dropping out of school to migrate with families in search of work is a major survival strategy for many impoverished families in India (Roy et al., 2015). Despite widespread acknowledgement within the seed industry about the existence and exploitation of child labour, only a few multinationals and local seed companies had taken efforts, through private policies, to help eradicate child labour. The Accimap resulting from the review is presented in Fig. 3 (Table 5).

Events such as 'subsistence farmers, funded by seed companies, forcing their children to work' acted as reference points to begin analysis at the 'labourers' and 'organisational' levels. Similar to the analysis carried out in Sect. 4.1, this analysis highlighted the impact of a complex set of interactions between multiple causal factors distributed across systemic levels leading to the illegal use of child labour in 2014/15 in GJ. The analysis presented in Fig. 3 underlines failures at multiple points. Here the farmers' level also consisted of additional stakeholders in the form of local seed producers whose actions caused negative impacts on labourers and their families. Fourteen causal factors were identified across the operational management levels. One indirect factor was identified at this level. A key difference between the Accimaps resulting from both the analyses is that while the 2003/04 incidents had a majority of profiteering-related factors, OCG activity was the most recurring causal factor in the 2014/15 illegal child labour incidents.

\section{Organisation of criminal activity}

The Accimap (Fig. 3) reveals that the illegal use of child labour was not just an outcome of individual non-compliances with public and private policies or the inadequacies of public policies alone, but was instead attributable to an accumulation of events. These included the state government's denial of the existence of child labour; intentional miscommunication about the role of child labour by organisations and the state government; trafficking of migrants; and the lack of duty of care for labourers' families. Of all the causal factors identified, 30.8\% were attributable to illicit activities. These factors were distributed across the 'Central Government', 'State Government', 'organisational', and 'operational management' (labour middlemen) levels. $62.5 \%$ of the factors at the 'State Government' level were attributable to OCG activity, while only one factor (inadequately designed national policies) at the 'Central Government' level was associated with the presence of organised crime. The common theme across both government levels was the inadequacy of public 
policies and a lack of commitment to eliminate child labour creating a compromised environment where organised crime could flourish. Intentional miscommunication was a causal factor at both, the 'State Government' as well as the 'Organisational' levels; both stakeholders intentionally and falsely reported that children working on family-run subsistence farms to help their parents either during school holidays or around school hours. Furthermore, seed companies also made false promises regarding the design of detailed private policies to help eliminate child labour in India. In comparison to the other levels, only $21.4 \%$ of the factors at the 'operational management' levels were attributable to organised exploitative behaviour and all of these factors were identified at the labour middle-men level. At the 'farmers and local seed producers' (operational management) level, control and coercion were the predominant causal factors. One outcome at the 'labourers' level was as identified as a form of highly organised OCG activity. Bivens and Shierholz (2018) argue that power inequality is the foundation for such labour exploitation driven by distance (especially for migrant workers), profiteering and oppression.

\section{Profiteering}

Similar to the 2004 report, only one causal factor (33.3\%) attributable to profiteering was identified at the 'Central Government' level. However, unlike the 2004 report, one profiteering-related causal factor (16.7\%) was also found at the 'external' level. Around a quarter $(23.1 \%)$ of the causal factors identified in the 2015 illegal child labour report were attributable to profiteering and were located all across the sociotechnical system. At the 'State Government' level there was one causal factor attributable to profiteering. A further two causal factors were identified at the 'organisational' level. Around a third of causal factors $(35.7 \%)$ attributable to profiteering were identified at the 'operational management' levels: one at 'farmers/local seed producers' level, while three were located at the 'labour middle-men' level. A further three outcomes (20\%) identified at the 'labourers' levels were also profit-related.

\section{Control and coercion}

Of the causal factors, $12.8 \%$ were attributable to control and coercion. One controlrelated causal factor $(12.5 \%)$ was at the 'organisational' level; four causal factors $(35.7 \%)$ at the 'operational management' levels; (two at the 'farmers/local seed producers' level, and two at the 'labour middle-men' level). A further third of outcomes at the 'labourers' level were related to control and coercion. Subsistence farming as a causal factor was unique to the $2014 / 15$ child labour incidents where organisations (seed companies) relocated to specific areas to avoid constant media attention related to child labour as well as loaning farmland to subsistence farmers. Further, local seed producers also loaned out seeds to subsistence farmers with loan agreements that included high interest rates and repayment schemes in the form of product and monetary outputs. Subsistence farmers in-turn had to over-rely on their family (including children) to meet loan terms and produce the desired output. These show examples of supply chain oppression (Shih 2020). 


\section{Recruitment}

In the 2014/15 illegal child labour incidents in GJ, only one causal factor (2.5\%) was attributable to recruitment, and it was located at the 'labour middle-men' (within the 'operational management') level. However, three (20\%) of the outcomes at the 'labourers' level were recruitment-related. Unlike the 2003/04 child labour incidents, causal factors attributable to recruitment in the 2014/15 child labour incidents were mostly focussed at the 'labourers' level.

\section{Discussion}

A range of stakeholders play a role in ensuring that the agri-food value chain is compliant with the ILO's policy on child labour (C182 - Worst Forms of Child Labour Convention 1999 (No. 182)). Stakeholders of interest here include central and local governments; regulators; senior leaders, board of directors and managers of transnational, national and local businesses; farmers; middle-men such as labour suppliers; and labourers. Human factors and by extension, a systems approach, emphasizes interactions between people and their environment, and its effect on performance, compliance, degree of safety, quality of work life, services offered, and the means adopted to offer services and products (Carayon et al. 2006). The importance of considering social constructs and interactions between the various elements of complex systems while designing policies has also been recommended in the healthcare, political, nuclear and transportation sectors (Branford 2011; Holden et al. 2013; Nayak and Waterson 2016a, b; Schneider and Sidney 2009). Although policies and guidelines are important in developing normative standards, designing a large number of guidelines from multiple sources makes it impossible for stakeholders to comply with them (Carthey et al. 2011). The use of Accimap analysis in this case study has shown the complexity of the causal factors leading to multiple negative outcomes associated with child labour. Similar to the 2003/04 child labour incidents, the causal factors in 2014/15 were linked in linear and downstream patterns. However, the complexity of the factors in the 2014/15 incidents was much greater. The analysis has not only highlighted multiple factors lead to the illegal use of child labour between 2014 and 2015, but also the presence of multiple secondary negative outcomes. These include lack of knowledge; unregulated working hours; increased rates of poverty; violation of national and international conventions; no provision of holidays; and non-functioning Workers' Unions. Although these outcomes indirectly lead to the illegal use of child labour, they also have a bigger role in either leading to the overall failure of the system, and also public and private policies meant to protect labour and child welfare and rights.

The Accimap analysis further establishes that although multiple public and private policies were designed as reactive measures post the 2003/04 child labour incidents, not only did illegal child labour continue, but also that the system and its stakeholders adapted their illegal activities around the findings of the 2004 report. For example, seed companies relocated to remote areas potentially to: avoid media and NGO attention; and bind tribal and poverty-stricken labourers into subsistence 
farming in return for cheap and bonded labour. This is an example of supply chain oppression and labour exploitation underpinned by an organised approach to the use of child labour. Le (2012) determines that organized crime models have a physical structure and mode of operation that focus on illicit activities, economics and enterprise and they are framed by cultural and social factors. It is reported that seed companies exploited poverty-stricken households that relied heavily on child labour (Dammert et al. 2018). Whilst governments, and seed companies designed multiple anti-trafficking policies (based on 'work-as-imagined'), in reality there were poor rates of compliance (with regards to work-as-done).

\section{Comparing the maturity of the child labour incidents}

In order to conceptualise the findings of this study, maturity models (Figs. 4 and 5) have been developed based on the findings from the Accimaps (Figs. 2 and 3 ), and the dimensions of modern slavery (Cooper et al., 2017). The four dimensions of modern slavery are in the inner-most circle, while the penultimate circle

\section{Child Labour Exploitation Maturity Stages for the 2003/04 incidents}

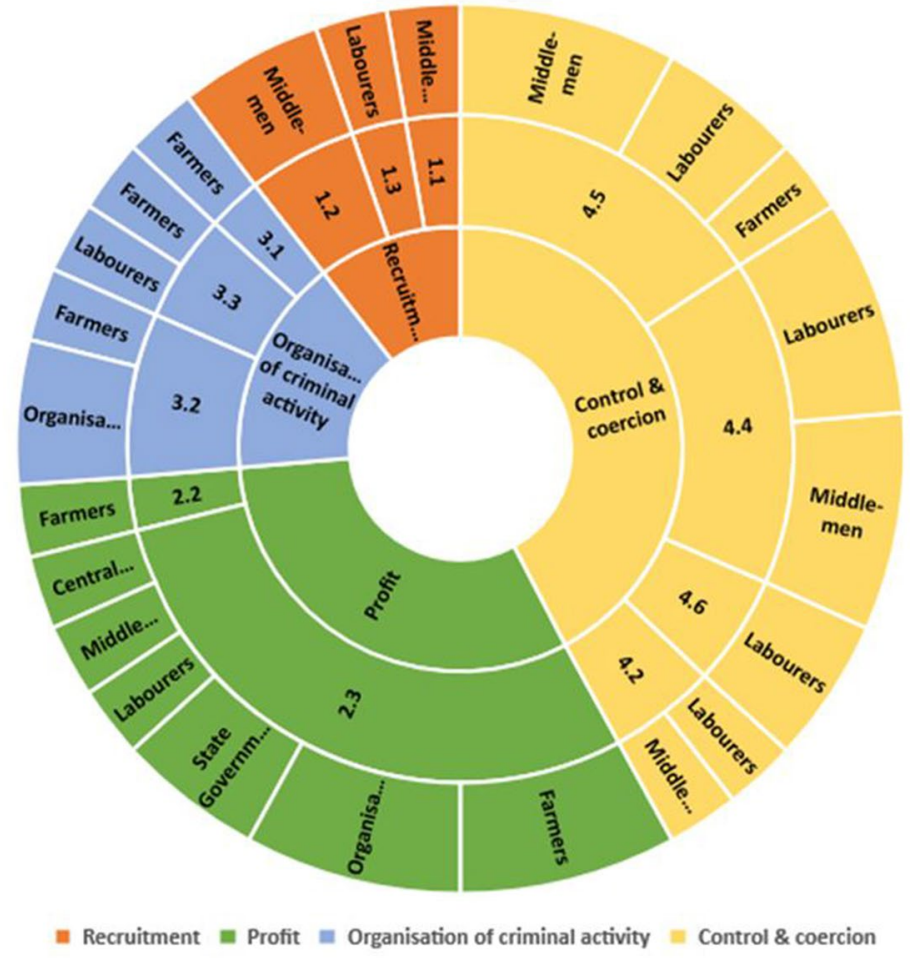

Fig. 4 Maturity stages of the causal factors and outcomes related to the 2003/04 illegal child labour incidents in Gujarat 


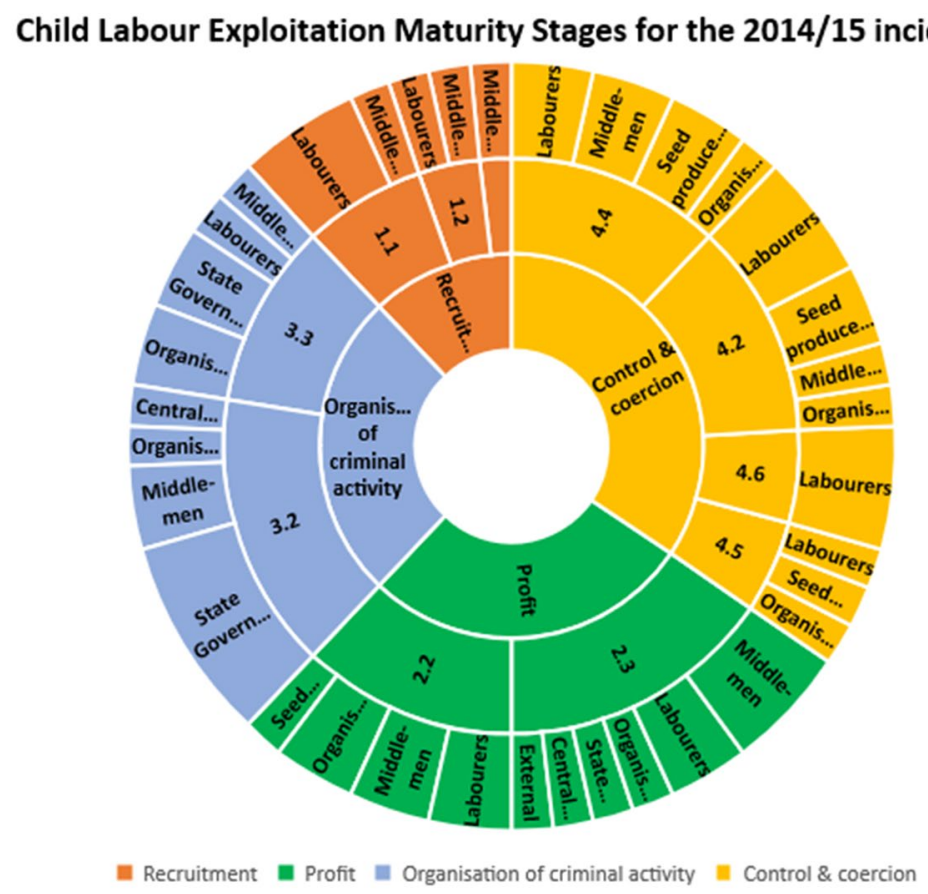

Fig. 5 Maturity stages of the causal factors and outcomes related to the 2014/15 illegal child labour incidents in Gujarat

highlights the maturity descriptors for each of the dimensions. Each dimension is represented by a different colour: recruitment (orange); control and coercion (yellow); organisation of criminal activity (blue); and profiteering (green). The outermost circle illustrates the number of causal factors and outcomes identified at each of the systemic levels, this is then categorised into the relevant maturity stages. The higher the number of causal factors and outcomes under each maturity descriptor, the larger the rectangle for each systemic level in the outermost circle.

The maturity of both complex systems shows recruitment was between victims approaching offenders to offenders targeting very vulnerable victims; profiteering occurs between limited financial gain to running like a business; OCG activity sits between minimal organisational to highly organised criminal activity; and control and coercion lies between threats and occasional violence to social isolation with the exception of substance-related coercion. Overall, the cottonseed sector in GJ had matured between 2003 and 2015 with regards to the level of maturity of exploitation and corruption, a cause for concern.

The causal factors associated with the 2003/04 illegal child labour incidents appear more opportunistic and less coordinated in terms of criminal activity (Manning, Smith and Soon 2016) when compared to the 2014/15 illegal child labour incidents. Stakeholders designed policy based on national and international regulations 
and conventions (legally compliant) without necessarily seeing how to operationalise them in real-world scenarios where it was impractical to implement or inactivate. The 2014/15 illegal child labour incidents, as has been shown in this paper, had an even distribution of causal factors and outcomes between two maturity stages: (1) limited financial gain; and (2) run like a business. Much like the longitudinal study by Levison et al. (2007), farm operators preferred child labour over adult labour for the reasons outlined previously in the paper. The pressure to be profitable starts high up the hierarchical value chain and creates a systematic interaction of influencers that directly, or indirectly, promotes the use of child labour to increase profit and return. Additionally, limited financial resources at the organisational level also enabled the reliance on child labour. India being a Less Economically Developed Country (LEDC) focusses on income generation via export of goods (United Nations 2014). Thus, Central Government is committed to export, leading to a public policy agenda of open competition between states to attract businesses. Consequently, GJ, among other states, sanctioned large areas of land for cottonseed production at low production costs. Financial constraints in LEDCs also have a negative impact on labour rights laws and policies (Blanton et al. 2015). Coercion and control took the forms of emotional control and social isolation. Working long hours in isolated locations perpetuates these forms of control as does the absence of a functional workers' union resulting in limited abilities to protect rights, and create fairer work environments (Tyler 2015).

When child exploitation is identified, the focus is on establishing the root cause and redesigning normative standards in public and private policies. However, it is important to note that root cause analysis alone and the reactive processes associated with it will not address system level faults in socio-political economies (Lebaron et al. 2018). In order to design effective policies that are based on a 'work as done' philosophy (Hollnagel 2014) it is the important to assess agri-food value chains and the associated regulatory framing as a whole and in a holistic, proactive manner. A better understanding of the mediating role of stakeholder attitudes in global food supply chains is needed alongside discrete audit tools to assess labour welfare in agriculture value chains. As a result of situational and organisational factors such as time pressure, availability of resources, workload, incentives/motivation and competition, stakeholders demonstrate varying degrees of policy compliance in complex sociotechnical systems (Bates and Holroyd 2012; Smith et al. 2017; Humaidi and Balakrishnan 2018). As has been shown in these case studies, external influences such as political and financial factors destabilise these systems leading to adaption and change. Maintaining control and delivering compliance during continual changes is thus a dynamic process involving the entire sociotechnical system (Svedung and Rasmussen 2002).

The study highlights the impact of human interactions with their internal and external environments. The findings suggest that it is vital to analyse human, organisational and government factors leading to the use of illegal and forced child labour from a systems lens while designing public and private policies. Adopting such an approach helps to identify the multiple causal factors and gain an in-depth insight into the functioning of agri-food value chains. A strong 'compliance and vigilance' culture combining system standards, audits, legal actions, formation of vigilance 
committees and strengthening of grievance committees is needed to reduce and eliminate the illegal practices and child labour incidents (Mishra 2001; Skrivankova 2014). However, whether a strict "citizenship oriented" model of regulatory compliance (Feldman 2011) would be a plausible and reliable approach in maintaining compliance by stakeholders amidst multiple socio-political pressures across hierarchical levels is still open to debate.

\section{Conclusion}

Systematic analysis of the 2003/04 and 2014/15 illegal child labour incidents and comparison with Rasmussen's framework highlights the complexity of causal factors and the importance of designing relevant policies based on 'work-as-done' rather than 'work-as-imagined' when developing public and private normative standards especially where there is a motive to protect multi-stakeholder self-interest in the exploitation of child labour. Non-compliance with normative standards with a focus on generating profit, was a major issue identified at the operational management and organisational levels. This combined with a lack of opacity, transparency, and integrity within the governance of labour supply chain across government, organisational and operational management levels. Indeed, external factors such as commercial pressures and NGOs focussing on different State Governments and locations put the entire system in the state of GJ under greater pressure, leading to wider exploitation. A lack of positively orientated shared values, attitudes, perceptions and behaviours of stakeholders combined with a lack of motivation to protect labour standards at the level of "work as done" means such exploitative practices will continue, even proliferate. The work described in this paper describes one methodological approach to assessing this issue, however, more empirical research needs to be carried out in this field of enquiry. The authors also acknowledge that the methodology adopted in this paper has several limitations, one of which is the dangers associated with hindsight bias, which is the tendency to exaggerate the predictability of outcomes after they have become known (Fessel et al. 2009). Knowing the outcome of events can distort any predictive judgements made on historic data and, the authors have been careful to not make any such predictions in the paper. The study does identify limitations and flaws associated with designing policies based on a "work-as-imagined" philosophy and demonstrates how the use of maturity modelling can explore how exploitation, corruption and organised crime is framed, and becomes more formalised over time.

\section{Declarations}

Conflict of interest The authors certify that they have NO affiliations with or involvement in any organization or entity with any financial interest (such as honoraria; educational grants; participation in speakers' bureaus; membership, employment, consultancies, stock ownership, or other equity interest; and expert testimony or patent-licensing arrangements), or non-financial interest (such as personal or professional relationships or affiliations) in the subject matter or materials discussed in this manuscript. 
Ethical approval This study involves an analysis of published reports. The Harper Adams University Research Ethics Committee has confirmed that no ethical approval is required.

Informed consent The research did not involve direct/indirect contact with human/animal participants. Document analyses were carried out in this study and hence, there was no requirement for Informed Consent.

\section{References}

Albanese J (2011) Organized crime in our times, 6th edn. Anderson Publishing, Burlington, MA

Aas K (2007) Globalization and crime. Sage, Los Angeles

Antonopoulos G, Shen A, Papanicolaou G (2013) China's stolen children: internal child trafficking in the People's Republic of China. Trends in Organized Crime 16:31-48

Assan J, Hill H (2011) Assan, J. and Hill, H. (2010) 'Practitioners' perspectives of child migrant labour and child exploitation within cotton seed fields: cases from Gujarat, India'. Law, Social Justice and Global Development Journal, 2

Bates S, Holroyd J (2012) Human factors that lead to non-compliance with standard operating procedures. Buxton. Available at: https://www.hse.gov.uk/research/rrpdf/rr919.pdf. Accessed 20 July 2020

Bivens J, Shierholz H (2018) What labor market changes have generated inequality and wage suppression? Available at: https://files.epi.org/pdf/148880.pdf. Accessed 20 July 2020

Blanton R, Blanton S, Peksen D (2015) Financial crises and labor: Does tight money loosen labor rights? World Dev 76:1-12

Branford K (2011) Seeing the big picture of mishaps. APAHF 1(1):31-37. https://doi.org/10.1027/ 2192-0923/a00005

Branford K, Naikar N, Hopkins A (2009) Guidelines for Accimap analysis Part A : Standardising the AcciMap approach the AcciMap approach. In: Hopkins A (ed) Learning from high reliability organisations. CCH, pp 193-212

Burea of International Labor Affairs (2018) 2018 Findings on the worst forms of child Labor: India. Washington D.C

Carayon P et al.(2006) Work system design for patient safety: The SEIPS model. Quality and Safety in Health Care, 15, pp 50-58. Available at: https:/qualitysafety.bmj.com/content/qhc/15/suppl_1/ i50.full.pdf. Accessed 20 July 2020

Carthey J, Walker S, Deelchand V, Vincent C, Griffiths WH (2011) Breaking the rules: understanding non-compliance with policies and guidelines. BMJ 343:d5283-d5283

Chand R, Srivastava SK (2014) Changes in the rural labour market and their implications for agriculture. Econ Polit Wkly, March(10):47-54

Charles M (2002) The growth and activities of organised crime in Bombay. Int Soc Sci J 53(169):359-367

Chocolate Manufacturers Association (2001) Protocol for the growing and processing of cocoa beans and their derivative products in a manner that complies with ILO Convention 182 concerning the prohibition and immediate action for the elimination of the worst forms of child labor. CMA, p. 16. Available at: http://www.cocoainitiative.org/en/documents-manager/english/54harkin-engel-protocol/file. Accessed 20 July 2020

Cooper C, Hesketh O, Ellis N, Adam FairHome Office Analysis and Insight (2017) A typology of modern slavery offences in the UK, research report 93 - home office analsyis and insight. London. Available at: https://www.antislaverycommissioner.co.uk/media/1190/a-typology-of-modern-slavery-offences.pdf. Accessed 20 July 2020

DAC\&FW (2019) Vigilance, government of India. Available at: http://agricoop.gov.in/divisiontype/ vigilance. Accessed 28 Apr 2020

Dammert A et al (2018) Effects of public policy on child labor: Current knowledge, gaps, and implications for program design. World Dev 110:104-123

Delap E (2001) Economic and cultural forces in the child labour debate: Evidence from Urban Bangladesh. J Dev Stud 37(4):1-22 
Department of Agriculture Cooperation \& Farmers Welfare (2020) Acts and rules, government of India. Available at: http://agricoop.nic.in/acts-and-rules-listing. Accessed 15 July 2020

Deshpande T (2017) State of agriculture in India, PRS Legislative research. New Delhi. Available at: https://www.prsindia.org/uploads/media/Analytical/Report/State/of/Agriculture/in/India.pdf. Accessed 20 July 2020

Directorate General of Foreign Trade (2015) Foreign Trade policy statement. Ministry of commerce and industry. Available at: http://dgft.gov.in/exim/2000/policy/FTP_Statement.pdf. Accessed 20 July 2020

Employees' State Insurance Corporation (1948) The employees' state insurance act. India. Available at: https://www.esic.nic.in/attachments/actfile/ae036213fec2e5ca97e2c9314a1fc9e9.pdf. Accessed 20 July 2020

Eurocontrol (2013) From safety-I to safety-II: A white paper

Farming Statistics (2016) Agricultural labour in England and the UK. Available at: http://foodresear ch.org.uk/wp-content/uploads/2016/07/Agricultural-labour-briefing-FINAL-4-July-2016.pdf. Accessed 20 July 2020

Feldman Y (2011) Five models of regulatory compliance motivation: Empirical findings and normative implications. In: Levi-Faur D (ed) Handbook on the Politics of Regulation, 1st edn. Edward Elgar, Cheltenham, pp 335-346

Fessel F, Epstude K, Roese NJ (2009) Hindsight bias redefined: It's about time, Organizational Behavior and Human Decision Processes. Elsevier Inc., 110(1), pp 56-64. https://doi.org/10.1016/j.obhdp. 2009.07.001

Fitzgibbon K (2003) Modern-day slavery? Afr Secur Rev 12:81-89

Gayi S, Tsowou K (2016) Cocoa industry : Integrating small farmers into the global value chain, United Nations Conference on Trade and Development. Geneva

Ghosh J (2020) A critique of the Indian government's response to the COVID-19 pandemic. Journal of Industrial and Business Economics 47:519-530

Government of India (1936) The payment of wages act. India. Available at: https://maitri.mahaonline. gov.in/pdf/payment-of-wages-act-1936.pdf. Accessed 20 July 2020

Government of India (1948) The minimum wages act. India. Available at: https://labour.gov.in/sites/defau 1t/files/TheMinimumWagesAct1948_0.pdf. Accessed 20 July 2020

Government of India (1951) Plantations labour act. India

Government of India (1955) Agricultural labour enquiry: Report on intensive survey of agricultural labour. Delhi

Government of India (1970) The contract labour (regulation and abolition) act. India. Available at: http:// labour.bih.nic.in/Acts/contract_labour_regulation_and_abolition_act_1970.pdf. Accessed 20 July 2020

Government of India (1976a) The bonded labour system (abolition) act. India. Available at: https://labour. gov.in/sites/default/files/TheBondedLabourSystem(Abolition)Act1976.pdf. Accessed 20 July 2020

Government of India (1976b) The equal remuneration act. India. Available at: https://indiacode.nic.in/ bitstream/123456789/1494/3/A1976-25.pdf. Accessed 20 July 2020

Government of India (1979) The inter-state migrant workmen (regulation of employment and conditions of service) act. India. Available at: https://indiacode.nic.in/bitstream/123456789/13209/1/the_ inter-state_migrant_workmen_regulation_of_employment_and_conditions_of_service_act_1979. pdf. Accessed 20 July 2020

Government of India (1986) The child labour (prohibition and regulation) act. India. Available at: https:// labour.gov.in/sites/default/files/act_3.pdf. Accessed 20 July 2020

Government of India (2015) The constitution of India (100th Ammendment). New Delhi, India: Government of India. Available at: https://www.india.gov.in/sites/upload_files/npi/files/coi_part_full.pdf. Accessed 20 July 2020

Government of India (2016) About the ministry, ministry of labour \& employment. Available at: https:// labour.gov.in/about-ministry. Accessed 30 Apr 2020

Government of India (2020) Union government ministries, GOI web directory. Available at: http://goidi rectory.nic.in/union_categories.php?ct=E002. Accessed 28 Apr 2020

Grimsrud B (2003) Millennium development goals and child labour. 43875. Rome. Available at: http:// documents.worldbank.org/curated/en/262041468141580732/Millennium-development-goals-andchild-labour. Accessed 20 July 2020

Gulati A, Jain S, Satija N (2013) Rising farm wages in India: The pull and push factors. Discussion Paper No 5. New Delhi 
Hilowitz J et al. (2004) Child labour: a textbook for university students. 1st edn. Edited by L. CarletonGertsch. Geneva: International Labour Office

Holden, R. J. et al. (2013) SEIPS 2.0: A human factors framework for studying and improving the work of healthcare professionals and patients, Ergonomics. Taylor \& Francis, 56(11), pp 1669-1686. Available at: https://doi.org/10.1080/00140139.2013.838643.

Hollnagel, E. et al. (2013) From safety I to safety II. Dublin.

Hollnagel E (2014) Safety-I and Safety-II: The Past and Future of Safety Management, 1st edn. Ashgate Publishing Company, Farnham

Humaidi N, Balakrishnan V (2018) 'Indirect effect of management support on users' compliance behaviour towards information security policies. Health Inf Manag J 47(1):17-27. Available at: https:// journals.sagepub.com/doi/full/https://doi.org/10.1177/1833358317700255

Hütz-Adams F (2010) Human rights in the cultivation of cocoa: An inventory of the initiatives of the cocoa and chocolate industry. In: Morrison R, O’Sullivan G (eds) International network of environmental forensics. RSC Publishers, Calgary

Ianni F (1972) A family business: kinship and social control in organized crime. Russell Sage Foundation, New York

International Labour Organization (1947) C081 - Labour inspection convention. Geneva: ILO. Available at: https://www.ilo.org/dyn/normlex/en/f?p=NORMLEXPUB:12100:0::NO:12100:P12100_ INSTRUMENT_ID:312226:NO. Accessed 20 July 2020

International Labour Organization (1999) C182 - Worst forms of child labour convention, 1999 (No. 182). Geneva: International Labour Organization. Available at: https://www.ilo.org/dyn/normlex/ en/f?p=NORMLEXPUB:12100:0::NO::P12100_ILO_CODE:C182. Accessed 20 July 2020

International Labour Organization (n.d.) What is Child Labour? International labour organization. Available at: https://www.ilo.org/wcmsp5/groups/public/---asia/---ro-bangkok/---ilo-yangon/documents/ publication/wcms_531953.pdf. Accessed 20 July 2020

International Programme on the Elimination of Child Labour (2013) Business and the fight against child labour: experience from India, Brazil and South Africa. Geneva: International Labour Office. Available at: file://C:/Users/00763700/Downloads/Businees_fight_Child_Labour_EN_20131025_ Web.pdf. Accessed 20 July 2020

Jenkins D et al (2010) A systemic approach to accident analysis: a case study of the Stockwell shooting. Ergonomics 53(1):1-17. https://doi.org/10.1080/00140130903311625

Kapadia K, Lerche J (1999) Introdcution. In: Byres T, Kapadia K, Lerche J (eds) Rural labour relations in India, 1st edn. Routledge, New York, pp 1-9

Kirlik A (2011) Sociotechnical systems, risk and error, in Human-Tech: Ethical and Scientific Foundations. Oxford University Press

Labour Employment and Manpower Division (2011) Report of the 12th plan working group on employment, planning and policy

Le V (2012) Organised crime typologies: Structure, activities and conditions. Int J Criminol Sociol $1: 121-131$

League of Arab States et al (2019) Child labour in the Arab Region: A quantitative and qualitative analysis, general secretariat. Cairo. https://doi.org/10.1017/CBO9781107415324.004

Lebaron G et al (2018) Confronting root causes: forced labour in global supply chains. Sheffield. Available at: http://speri.dept.shef.ac.uk/2018/01/10/new-study-identifies-innovative-approaches-totackle-forced-labour-in-global-supply-chains/. Accessed 20 July 2020

Levison D, Hoek J, Lam D, Duryea S (2007) Intermittent child employment and its implications for estimates of child labour. Int Labour Rev 146:217-251

Manning L, Smith R, Soon JM (2016) Developing an organizational typology of criminals in the meat supply chain. Food Policy 59:44-54

Michelutti L, Martin N (2017) Protection rackets and party machines: Comparative ethnographies of "Mafia Raj" in North India. Asian J Soc Sci 45(6):693-723

Ministry of Law and Justice (2008) The unorganised workers' social security act. India. Available at: https://www.ilo.org/dyn/travail/docs/686/UnorganisedWorkersSocialSecurityAct2008.pdf. Accessed 20 July 2020

Mishra L (2001) A perspective plan to eliminate forced labour in India, ILO InFocus programme on promoting the declaration on fundamental principles and rights at work. Declaration/WP/2/2001. Geneva. Available at: http://www.oit.org/wcmsp5/groups/public/---ed_norm/---declaration/docum ents/publication/wcms_decl_wp_2_en.pdf. Accessed 20 July 2020 
Mistrati M, Romano U (2010) The dark side of chocolate. Denmark: Bastard Film \& TV. Available at: https://youtu.be/7Vfbv6hNeng. Accessed 20 July 2020

Morgan J, Olsen W (2015) The absence of decent work: the continued development of forced and unfree labour in India. Global Labour Journal 6(2):173-188

Motiram S (2007) Attached labor contracts in agriculture: Results and analysis from a survey in South India. Can J Dev Stud 28(1):99-117

National Statistical Office (2019) Periodic labour force survey (PLFS). New Delhi. Available at: https:// www.mospi.gov.in/sites/default/files/publication_reports/AnnualReport\%2CPLFS2017-18_31052 019.pdf. Accessed 20 July 2020

Nayak R, Waterson P (2016a) 'The Assessment of Food Safety Culture: An investigation of current challenges, barriers and future opportunities within the food industry', Food Control. Elsevier Ltd, 73(B), pp. 1114-1123. Available at: http://linkinghub.elsevier.com/retrieve/pii/S09567135163057 22. Accessed 20 July 2020

Nayak R, Waterson P (2016) When Food Kills: A socio-technical systems analysis of the UK Pennington 1996 and 2005 E.coli O157 Outbreak reports. Saf Sci 86:36-47. https://doi.org/10.1016/j.ssci. 2016.02.007

Nayak R, Waterson P (2019) Global food safety as a complex adaptive system: Key concepts and future prospects. Trends Food Sci Technol 91:409-425. https://doi.org/10.1016/j.tifs.2019.07.040

Nepal A, Nepal M (2012) Is child labour a substitute for adult labour? The relationship between child labour and adult illness in Nepal. Int Labour Rev 151(1-2):109-121

Nzewi O et al (2018) Creating compliance value through informal work procedures. Cogent Soc Sci Cogent 4(1):1-17. https://doi.org/10.1080/23311886.2018.1551828

Office on Drugs and Crimes (2004) United nations convention against transnational organized crime and the protocols thereto. New York

O'Keefe B (2016) Inside big chocolate's child labor Problem. Fortune, p 19

O'Reilly C, De Cock M, Mahendran N (2015) Insights into working conditions in India's garment industry. 1st edn, International Laboor Office. 1st edn. Geneva

Pennington H (2009) The public inquiry into the September 2005 outbreak of, (September 2005)

Pennington TH (2003) When food kills: BSE, E.coli and disaster science, 1st edn. Oxford University Press, Oxford

Rasmussen J (1997) Risk management in a dynamic society: A modelling problem. Saf Sci 27(2):183213. https://doi.org/10.1016/S0925-7535(97)00052-0

Reason J (2000) Human error: models and management. BMJ 320(7237):768-770

Rena R (2009) The Child Labor in Developing Countries: A Challenge to Millennium Development Goals. Indus Journal of Management \& Social Sciences 3(1):1-8

Roy AK, Singh P, Roy UN (2015) Impact of rural-urban labour migration on education of children: A case study of left behind and accompanied migrant children in India. Space Cult India 2:17

Ruehle RC et al. (2017) Bitter Sweet: Child labor in the chocolate industry - a clear case of double standards? Wittenberg Center for Global Ethics p 27. Available at: https://www.researchgate.net/publi cation/326106773_Bitter_Sweet_Child_labor_in_the_chocolate_industry_-_a_clear_case_of_double_standards. Accessed 20 July 2020

Schneider A, Sidney M (2009) What Is next for policy design and social construction theory? Policy Stud J 37(1):103-119. https://doi.org/10.1111/j.1541-0072.2008.00298.x

Schrage E, Ewing A (2005) The cocoa industry and child labour. Journal of Corporate Citizenship 18:99-112

Sengupta A et al. (2007) Report on conditions of work and promotion of livelihoods in the unorganised sector, government of India. New Delhi. Available at: https://dcmsme.gov.in/Condition_of_worke rs_sep_2007.pdf. Accessed 20 July 2020

Seth R (2013) Child Labour. In: Srivastava R, Seth R, von Niekerk J (eds) Child Abuse and Neglect: Challenges and Opportunities. JP Medical Publishers, New Delhi, pp 79-85

Sharath A (2019) Agriculture labour problem in India. Southern Economist 57(22):18-24

Sharma ML (1999) 'Organised crime in India: problems and perspectives'. In: UNAFAI (ed) 108th International Seminar Visiting Expers’ Papers. Fuchu, pp 82-129. Available at: https://unafei.or.jp/publi cations/pdf/RS_No54/No54_10VE_Sharma.pdf. Accessed 20 July 2020

Shih W (2020) Is it time to rethink globalized supply chains? MIT Sloan Management Review, March, p. Online

Singh S (2017). In: Noronha E, D’Cruz P (eds) Critical perspectives on work and employment in globalizing India. Springer, Singapore, pp 15-36 
Skrivankova K (2014) Forced labour in the United Kingdom. York. Available at: https://www.gla.gov.uk/ media/1584/jrf-forced-labour-in-the-uk.pdf. Accessed 20 July 2020

Smith R, Manning L, McElwee G (2017) Critiquing the inter-disciplinary literature on food-fraud. Int J Rural Crime 3(2):250-270

Smit M (2011) 'Trafficking in human beings for labour exploitation. The Case of the Netherlands', Trends in Organized Crime 14:184-197

Srivastava RN (2019) Children at work, child labor and modern slavery in India: An Overview. Indian Pediatr 56(8):633-638

Svedung I, Rasmussen J (2002) Graphic representation of accident scenarios: Mapping system structure and the causation of accidents. Saf Sci 40:397-417. https://doi.org/10.1016/S0925-7535(00) 00036-9

Taylor F (1911) The principles of scientific management. 1st edn. Harper \& Brothers

Tyler G (2015) Look for the Union Label: History of the international ladies' garment workers' Union. Routledge, Abingdon

Underwood P, Waterson P (2014) 'Systems thinking, the Swiss Cheese Model and accident analysis: A comparative systemic analysis of the Grayrigg train derailment using the ATSB, AcciMap and STAMP models', Accident analysis and prevention. Elsevier Ltd 68:75-94. https://doi.org/10. 1016/j.aap.2013.07.027

United Nations (2014) 'Country Classification', in world economic situation and prospects. Illustrate. United Nations Publications, pp. 143-150

United Nations General Assembly (1989) Convention on the rights of the child. New York

United Nations General Assembly (2015) Transforming our world: The 2030 agenda for sustainable development

Venkateswarlu D (2004a) Child labour in hybrid cottonseed production in Andhra Pradesh: Recent Developments. Utrecht. Available at: http://www.indianet.nl/cotseed2.html. Accessed 20 July 2020

Venkateswarlu D (2004b) Child labour in hybrid cottonseed production in Gujarat and Karnataka. Utrecht. Available at: http://www.indianet.nl/gujakarn.html. Accessed 20 July 2020

Venkateswarlu, D. (2015) Cotton's Forgotten Children: Child Labour and Below Minimum Wages in Hybrid Cottonseed Production in India. Utrecht. Available at: https://arisa.n1/wp-content/uploads/ CottonsForgottenChildren.pdf. Accessed 20 July 2020

Webbink E, Smits J, de Jong E (2012) Hidden child labor: Determinants of housework and family business work of children in 16 developing countries. World Dev 40(3):631-642

Weske U et al (2018) Using regulatory enforcement theory to explain compliance with quality and patient safety regulations: The case of internal audits. BMC Health Services Research Springer Nature 18(62):1-6

Publisher's note Springer Nature remains neutral with regard to jurisdictional claims in published maps and institutional affiliations. 